\title{
Estimation of Global Solar Radiation on Horizontal Surface from Sun Shine Hours and Temperature at Kombolcha, Amhara Region, Ethiopia
}

\author{
Tegenu Argaw Woldegiyorgis \\ Department of Physics, Wollo University, Dessie, Ethiopia \\ Email address: \\ argaw2009@gmail.com
}

\section{To cite this article:}

Tegenu Argaw Woldegiyorgis.Estimation of Global Solar Radiation on Horizontal Surface from Sun Shine Hours and Temperature at Kombolcha, Amhara Region, Ethiopia. Journal of Energy, Environmental \& Chemical Engineering. Vol. 4, No. 3, 2019 , pp. $39-46$. doi: $10.11648 /$ j.jeece.20190403.12

Received: August 11, 2019; Accepted: October 17, 2019; Published: November 8, 2019

\begin{abstract}
The detailed knowledge of the local solar radiation is important but, measuring instruments are not readily available in many places, particularly in Ethiopia. Therefore, this work focused on the application of climate data to compare sunshine and temperature based empirical equation of the global solar radiation in Kombolcha sites, Amhara region, Ethiopia. For data obtained in a period of 2008 to 2017 from the Kombolcha meteorological agency correlations be tested for errors using: Mean Bias error (MBE), Root Mean Square Error (RMSE), Mean Percentage Error (MPE), and correlation Coefficient (r). The latest computing MATLAB soft ware and excel spread sheet has been used for the entire analysis. The empirical equation having the least error was selected for Kombolcha sites. Therefore, according to accuracy the Hargreaves and Samani empirical equation is suitable for Kombolcha sites than Angstrom-Prescott empirical equation. The abundant average global solar radiation of $6.19 \mathrm{KWh} / \mathrm{m}^{2} /$ day and $7.09 \mathrm{KWh} / \mathrm{m}^{2} /$ day was estimated using sun shine and temperature based empirical equation respectively. This result showed that there is good solar potential in Kombolcha, Amhara region, Ethiopia.
\end{abstract}

Keywords: Meteorological Parameters, Extraterrestrial Solar Radiation, Global Solar Radiation

\section{Introduction}

Electricity access in Ethiopia is one of the lowest in the Africa. Only 25 percent of the population has access to electricity while the geographic electricity network coverage reaches 60 percent (GTP II, 2015). The country is endowed with huge renewable energy resources including hydro, wind, geothermal, solar and bio-energy. Hence, enhancing adequate, reliable, and affordable electricity access is vital for the country's socio-economic development and transformation since it is a key input to all sectors in the economy. The electricity access challenge in the country has also been further intensified with increasing population and rapid urbanization in addition to the increasing electricity demand in already electrified urban areas due to the modern life style and expanding industrialization [1].

Solar radiation is the driving force of both the physical and biological cycles on the earth. Consequently, it then becomes pertinent to have very good knowledge of current and past records of solar radiation at a location so as to aid in the estimation of the performance of any solar energy system [2]. Solar radiation data are a fundamental input for solar energy applications such as photovoltaic and solar thermal systems. Accurate design of solar energy systems requires proper knowledge of global solar radiation falling on the earth's surface. Solar radiation measurements are not always available due to the cost of the measuring equipment. Thus solar radiation models are needed to predict the solar radiation [3]. In most developing countries, there are no properly recorded radiation data. What is usually available is sun- shine duration data obtained by a sunshine recorder. Ethiopia is one of such country, which lacks properly recorded solar radiation data like many other countries. However, from the given number of sunshine hours and local atmospheric conditions data (relative humidity, rain fall, maximum and minimum temperature) with the help of empirical model the daily average solar radiation can be estimated [4]. According to World Meteorological 
Organization (WMO, 2003), sun shine duration during a given period is defined as the sum of those sub- periods for which the direct solar irradiance exceeds $120 \mathrm{Wm}^{2}$. Since Ethiopia is situated very close to the equator (between $30^{\circ}$ and $15^{\circ}$ degrees North) and share enough amount of solar energy potential which can be collected and put to use in the form of both thermal as well as electrical energy. The daily average total solar radiation over Ethiopia ranges from 5 to $8 \mathrm{KWh} / \mathrm{m}^{2}$ per day. In terms of geographical distribution, solar radiation that reaches the surface increases as one travels from west to east. The insolation period is approximately 2200 hours of bright sunshine per year in the west increasing to over 3300 hours per year in the eastern semi-arid regions. The minimum average solar radiation for the most part of the country is said to be about 5.3 $\mathrm{KWh} / \mathrm{m}^{2} /$ day [6]. In the past, a large number of researchers have used Sun shine based empirical equation and Angstrom-type correlation model to estimate the global solar radiation on a horizontal surface [7-13]. There is no finding that have been done before at a kombolcha sites to estimate the global solar radiation using the sun-shine and temperature based empirical equations. Moreover, the researcher is interested to study the global solar radiation for the application of Photovoltaic (PV) and solar thermal systems in the future as well as to select appropriate empirical equation to the sites.Therefore, the paper was focused on the use of climate data such as sunshine hours, minimum, maximum and average temperature from Kombolcha Meteorological agency for a period of 10 years to compare sun-shine and temperature based empirical equations for estimation of the global solar radiation in Kombolcha sites, Amhara region, Ethiopia. For the data obtained from the Kombolcha Meteorological agency correlations be tested for errors using: Mean Bias Error (MBE), Root Mean Square Error (RMSE), Mean Percentage Error (MPE) and correlation coefficient (r). The latest computing MATLAB software and excel spread sheet has been used for the entire analysis.

\section{Materials and Methods}

\section{Description of the research site}

Kombolcha, located in South Wollo Zone of Amhara Region, is one of the growing industrial centers of Ethiopia. The city is roughly equidistant from some of the country's largest urban centers (Addis Ababa $(377 \mathrm{~km})$, Mek'ele (400 $\mathrm{km})$ and Bahir Dar $(505 \mathrm{~km}))$. Kombolcha is located on latitude and longitude of $11.0816^{\circ} \mathrm{N}$ and $39.7434^{\circ} \mathrm{E}$ respectively. It has an altitude of $1863.96 \mathrm{~m}$ above sea level. In this paper ten years (2008-2017) sun shine hours, minimum temperature, maximum temperature and average temperature were obtained from the Kombolcha Metrological Agency. The measured global solar radiation data was obtained from NASA. Since NASA Surface Meteorology and Solar Energy (SSE) have record of solar radiation data all over the world, measured from satellite [14].

\section{Models}

\subsection{Temperature Based Model}

According to Hargreaves and Samani (1985), the difference between the maximum and minimum temperature is related to the degree of cloud cover in a given location. Clear sky conditions result in high temperatures during the day $\left(T_{\max }\right)$ because the atmosphere is transparent to the incoming solar radiation and in low temperatures during the night $\left(\mathrm{T}_{\min }\right)$ because less outgoing long wave radiation is absorbed by the atmosphere. On the other hand, in overcast conditions, $\mathrm{T}_{\max }$ is relatively smaller because a significant part of the incoming solar radiation never reaches the earth's surface and is absorbed and reflected by the clouds. Similarly, $\mathrm{T}_{\text {min }}$ will be relatively higher as the cloud cover acts as a blanket and decreases the outgoing long wave radiation. Therefore, the differences between the maximum and minimum temperature $\left(\mathrm{T}_{\max }-\mathrm{T}_{\min }\right)$ can be used as an indicator of the fraction of extraterrestrial radiation that reaches the earth's surface. [16]. Hargreaves and Samani proposed a simple model to estimate global solar irradiation $(\mathrm{H})$ using the maximum $\left(\mathrm{T}_{\max }\right)$ and minimum $\left(\mathrm{T}_{\min }\right)$ air temperatures and the extraterrestrial solar irradiation $\left(\mathrm{H}_{\mathrm{o}}\right)$. The Hargreaves-Samani model is based on the correlation between the global atmospheric transmittance $\left(\mathrm{C}_{\mathrm{r}}=\mathrm{H} / \mathrm{H}_{\mathrm{o}}\right)$ and the daily thermal amplitude $\left(\Delta \mathrm{T}=\mathrm{T}_{\max }-\mathrm{T}_{\min }\right)[16,17]$. According to Hargreaves and Samani models' estimated global solar radiation from the difference in the maximum and minimum temperature is

$$
H=H_{o} K_{r}\left(T_{\max }-T_{\min }\right)^{0.5}
$$

Where $\mathrm{H}$ is the solar radiation $\left(\mathrm{MJm}^{-2} \mathrm{day}^{-1}\right), \mathrm{H}_{\mathrm{o}}$ is the extraterrestrial radiation $\left(\mathrm{MJm}^{-2} \mathrm{day}^{-1}\right)$,

$\mathrm{T}_{\max }$ is the maximum temperature $\left({ }^{\circ} \mathrm{C}\right), \mathrm{T}_{\min }$ is the minimum temperature $\left({ }^{\circ} \mathrm{C}\right)$ and $\mathrm{K}_{\mathrm{r}}$ is the empirical coefficient which is recommended to be 0.16 for interior regions and 0.19 for coastal regions.

\subsection{Sun Shine Based Model}

The correlation proposed for estimating the monthly mean daily global solar radiation on a horizontal surface using the sunshine duration and clear sky radiation $\left(\mathrm{H}_{\mathrm{c}}\right)$ data was due to Angstrom [18].

$$
\frac{H}{H_{c}}=a+b\left(\frac{n}{N}\right)
$$

Because there may be problems in calculating clear sky radiation accurately, by replacing clear sky radiation with extraterrestrial radiation $\left(\mathrm{H}_{0}\right)$, the Angstrom correlation was put in more convenient form by Prescott $[19,20]$ and others have modified the method using the value of the extraterrestrial radiation on a horizontal surface rather than the 'clear day radiation' [4]. 


$$
\frac{\bar{H}}{\overline{H_{o}}}=a+b\left(\frac{\bar{n}}{\bar{N}}\right)
$$

Where $\bar{H}$ is the monthly average daily global radiation on a horizontal surface $\left(\mathrm{MJm}^{-2} \mathrm{day}^{-1}\right), \mathrm{H}_{0}$ is the daily extraterrestrial radiation on a horizontal surface $\left(\mathrm{MJm}^{-2} \mathrm{day}^{-1}\right), \mathrm{n}$ is the monthly average daily hours of bright sun shine, $\mathrm{N}$ is the monthly average day length, and(a and $\mathrm{b})$ values are known as angstrom empirical constant or regression coefficients. Their values have been obtained from the relationship given by [22] and confirmed by [23] as;

$$
\begin{gathered}
a=-0.110+0.235 \cos (\varphi)+0.323\left(\frac{\bar{n}}{\bar{N}}\right) \\
b=1.449-0.553 \cos (\varphi)-0.694\left(\frac{\bar{n}}{\bar{N}}\right)
\end{gathered}
$$

The monthly average daily extraterrestrial irradiation $\mathrm{H}_{0}$, be calculated from the equation below and given by $[21,24$, $25,26,27]$.

$$
\begin{gathered}
H_{o}=\frac{24 I_{O}}{\pi}\left[1+0.033 \cos \left(\frac{360 D}{365}\right)\right] \\
{\left[\cos (\varphi) \cos (\delta) \sin (\varpi)+\frac{\pi \varpi}{180} \sin (\varphi) \sin (\delta)\right]} \\
H_{O}=\frac{24 E_{o}}{\pi}\left[\cos (\varphi) \cos (\delta) \sin (\varpi)+\frac{\pi \varpi}{180} \sin (\varphi) \sin (\delta)\right]
\end{gathered}
$$

Where

$$
E_{o}=\left[1+0.033 \cos \left(\frac{360}{365}\right)\right.
$$

and

$$
I_{\mathrm{sc}}=\frac{1367 \times 3600}{1000000}\left(\mathrm{MJm}^{-2} \mathrm{day}^{-1}\right)
$$

Where $\mathrm{I}_{\mathrm{sc}}$ is the solar constant with numerical value of $1367 \mathrm{~W} / \mathrm{m}^{2}$ and can also be expressed in $\left(\mathrm{MJm}^{-2} \mathrm{day}^{-1}\right)$ in equation. $E_{0}$ is the eccentricity correction factor expressed in equation. $\varphi$ is the latitude of the site under study, is the solar inclination angle given as;

$$
\delta=23.45 \cos \left(\frac{284+D}{365}\right)
$$

Where $\mathrm{D}$ is the characteristic day number for each month: $\mathrm{D}=1$ on $1^{\text {st }}$ of January and $\mathrm{D}=365$ on $31^{\text {st }}$ of December. $\varpi$ is the mean sunrise hour angle for the given month expressed as;

$$
\varpi=\cos ^{-1}[-\tan (\varphi) \tan (\delta)]
$$

The day length $\mathrm{N}$ is the number of hours of sunshine within the 24 hours in a given day. The mean day $\mathrm{N}$ length is expressed as;

$$
\bar{N}=\frac{2}{15} \cos ^{-1}[-\tan (\varphi) \tan (\delta)]
$$

\section{Statistical Error Test}

Statistical data analysis was used to test the accuracy of the estimated global solar radiation values. The equations for root mean square error (RMSE), mean bias error (MBE) and mean percentage error (MPE) are given as [28-38];

$$
\begin{aligned}
\mathrm{RMSE} & =\sqrt{\sum_{i=1}^{n}\left(\frac{H_{\mathrm{ei}}-H_{\mathrm{mi}}}{n}\right)^{2}} \\
\operatorname{MBE} & =\frac{1}{n} \sum_{i=1}^{n}\left(H_{\mathrm{mi}}-H_{\mathrm{ei}}\right) \\
\mathrm{MPE} & =\sum_{i=1}^{n}\left(\frac{H_{\mathrm{ei}}-H_{\mathrm{mi}}}{H_{\mathrm{ei}}}\right) \quad \mathrm{v}
\end{aligned}
$$

The coefficient of correlation ( $r$ ) is given as follow [39].

$$
r=\frac{\sum_{i=1}^{n}\left(H_{\mathrm{mi}} H_{\mathrm{ei}}-n\left(\overline{H_{\mathrm{mi}}}\right) \overline{\left(H_{\mathrm{ei}}\right)}\right)}{\left(\sqrt{\sum_{i=1}^{n}\left(H_{\mathrm{mi}}\right)^{2}-n\left(\overline{H_{\mathrm{mi}}}\right)^{2}}\right)\left(\sqrt{\sum_{i=1}^{n}\left(H_{\mathrm{ei}}\right)^{2}-n\left(\overline{H_{\mathrm{ei}}}\right)^{2}}\right)}
$$

Where $\mathrm{n}$ is total number of observed data in a year, and are yearly mean measured and estimated. The above mentioned statistical equations are used to test the performance of the two models used for estimating global solar radiations. Low values of root mean square error (RMSE), mean bias error (MBE), mean percentage error (MPE) and correlation coefficient $r$ are desirable. RMSE tests provide information on the short term performance whereas MBE and MPE tests provide information on long- term performance. Since the model is expected to 'explain' most of the observed trends, then It is important to know how much RMSE is systematic and what portion of data is unsystematic. For a good model,

\begin{tabular}{|c|c|c|c|c|c|c|c|c|c|}
\hline Month & $\delta$ (deg.) & $\varpi$ (deg.) & $\mathbf{a}$ & B & $H_{0}\left(K W h / \mathrm{m}^{2} / \mathrm{d}\right)$ & n(hours) & N(hours) & $H_{\text {est }}\left(K W h / \mathrm{m}^{2} / \mathrm{d}\right)$ & $H_{\text {mea }}\left(K W h / \mathrm{m}^{2} / \mathrm{d}\right)$ \\
\hline Jan & 21.29 & 94.40 & 0.29 & 0.36 & 8.59 & 8.52 & 12.59 & 5.54 & 7.34 \\
\hline Feb & -13.67 & 92.75 & 0.3 & 0.34 & 9.39 & 8.81 & 12.37 & 6.21 & 7.48 \\
\hline Mar & -2.89 & 90.58 & 0.3 & 0.34 & 10.17 & 8.66 & 12.08 & 6.77 & 7.79 \\
\hline May & 18.74 & 86.21 & 0.3 & 0.34 & 10.42 & 8.21 & 11.49 & 6.8 & 8.15 \\
\hline June & 23.30 & 85.18 & 0.29 & 0.41 & 10.23 & 7.77 & 11.36 & 6.68 & 8.24 \\
\hline
\end{tabular}
the systematic difference should approach zero. MBE is actually the difference between the model predicted values and the observed.

\section{Result and Discussion}

For many developing countries, particularly in Ethiopia, global solar radiation measurements are not easily available due to the cost of measuring equipment's. It is therefore necessary to use empirical equations for estimating the global solar radiation based on the readily available meteorological parameters such as sun-shine duration and temperature. In this work sun-shine and temperature were used to evaluate and select suitable empirical formulas in order to estimate global solar radiation in kombolcha, Amhara region, Ethiopia.

Table 1. Comparison between Measured Solar Radiation and Estimated solar radiation from sun-shine hours. 


\begin{tabular}{llllllllll}
\hline Month & $\boldsymbol{\delta}$ (deg.) & $\boldsymbol{\varpi}(\mathbf{d e g}$.) & $\mathbf{a}$ & $\mathbf{B}$ & $\mathbf{H}_{\mathbf{0}}\left(\mathbf{K W h} / \mathbf{m}^{2} / \mathbf{d}\right)$ & $\mathbf{n}(\mathbf{h o u r s})$ & $\mathbf{N}(\mathbf{h o u r s})$ & $\mathbf{H}_{\text {est }}\left(\mathbf{K W h} / \mathbf{m}^{2} / \mathbf{d}\right)$ & $\mathbf{H}_{\text {mea }}\left(\mathbf{K W h} / \mathbf{m}^{2} / \mathbf{d}\right)$ \\
\hline July & 21.56 & 85.58 & 0.26 & 0.44 & 10.27 & 6.31 & 11.41 & 6.11 & 8.54 \\
Aug & 13.87 & 87.25 & 0.25 & 0.46 & 10.42 & 6.02 & 11.63 & 6.23 & 8.51 \\
Sep & 2.32 & 89.56 & 0.27 & 0.42 & 10.28 & 6.91 & 11.94 & 6.16 & 8.18 \\
Oct & -9.50 & 91.89 & 0.29 & 0.37 & 9.65 & 8.22 & 12.25 & 5.97 & 7.64 \\
Nov & -19.08 & 93.9 & 0.29 & 0.35 & 8.79 & 8.6 & 12.52 & 5.45 & 7.15 \\
Dec & -23.32 & 94.88 & 0.29 & 0.36 & 8.23 & 8.57 & 12.65 & 5.42 & 7.87 \\
Ave & - & - & 0.29 & 0.38 & 9.75 & 7.92 & 12.00 & 6.19 & 7.9 \\
\hline
\end{tabular}

According to Table 1, the maximum value of the monthly average daily global radiation using sun shine hours from (2008-2017) was estimated to be $6.96 \mathrm{KWh} / \mathrm{m}^{2} / /$ day in April. The minimum value of the monthly average daily global radiation was $5.42 \mathrm{KWh} / \mathrm{m}^{2} /$ day during December. The average global solar radiation that estimated by Angstrom-Prescott empirical equation was 6.19 $\mathrm{Kwh} / \mathrm{m}^{2} / /$ day.

Table 2. Comparison between Measured Solar Radiation and Estimated solar radiation from temperature.

\begin{tabular}{|c|c|c|c|c|c|}
\hline Month & $\delta$ (deg.) & $\varpi$ (deg.) & $H_{0}\left(K W h / \mathrm{m}^{2} / \mathrm{d}\right)$ & $H_{\text {est }}\left(K W h / \mathrm{m}^{2} / \mathrm{d}\right)$ & $H_{\text {mea }}\left(K W h / \mathrm{m}^{2} / \mathbf{d}\right)$ \\
\hline Jan & 1.29 & 94.40 & 8.59 & 6.23 & 7.34 \\
\hline Feb & -13.67 & 92.75 & 9.39 & 7.01 & 7.48 \\
\hline Mar & -2.89 & 90.58 & 10.17 & 7.53 & 7.79 \\
\hline Apr & 9.34 & 88.17 & 10.53 & 7.98 & 7.95 \\
\hline May & 18.74 & 86.21 & 10.42 & 7.95 & 8.15 \\
\hline June & 23.30 & 85.18 & 10.23 & 7.76 & 8.24 \\
\hline July & 21.56 & 85.58 & 10.27 & 6.87 & 8.54 \\
\hline Aug & 13.87 & 87.25 & 10.42 & 7.19 & 8.51 \\
\hline Oct & -9.50 & 91.89 & 9.65 & 6.84 & 7.64 \\
\hline Nov & -19.08 & 93.9 & 8.79 & 6.66 & 7.15 \\
\hline Dec & -23.32 & 94.88 & 8.23 & 5.59 & 7.87 \\
\hline Ave & - & - & 9.75 & 7.09 & 7.9 \\
\hline
\end{tabular}

According to Table 2, the maximum value of the monthly average daily global radiation using temperature from (2008-2017) was estimated to be $7.98 \mathrm{KWh} / \mathrm{m}^{2} / /$ day in April. The minimum value of the monthly average daily global radiation was $5.59 \mathrm{KWh} / \mathrm{m}^{2} /$ day during December. The two models discussed above are used to calculate the global solar radiation from sun-shine hours and temperature at Kombolcha sites, Amhara region, Ethiopia. The estimated values from sun shine hours with measured by NASA are shown in Table1 and Figure 1, and from temperature with measured by NASA are shown in Table 2 and Figure 2. The maximum monthly average global solar radiation for both model are occurred on April, which is $7.98 \mathrm{KWh} / \mathrm{m}^{2} /$ day for temperature based model and $6.96 \mathrm{KWh} / \mathrm{m}^{2} /$ day from sun shine based model. The minimum monthly averages are occurred in December, which is $5.59 \mathrm{KWh} / \mathrm{m}^{2} /$ day for temperature based model and $5.42 \mathrm{KWh} / \mathrm{m}^{2} /$ day for sun shine based model.

Table 3. Validation of the models under different statistical tests.

\begin{tabular}{lll}
\hline Statistical test & $\begin{array}{l}\text { Sun-shine based } \\
\text { empirical equation }\end{array}$ & $\begin{array}{l}\text { Temperature based } \\
\text { empirical equation }\end{array}$ \\
\hline RMSE & 1.31 & 0.9 \\
MBE & 1.71 & 0.81 \\
MPE & 0.22 & 0.10 \\
R & 0.54 & 0.07 \\
\hline
\end{tabular}

Statistical parameters such as RMSE, MBE, MPE and $r$ are used to determine the statistical test. The validation of the proposed empirical equation to estimate solar radiation for Kombolcha sites have been shown in table 3.

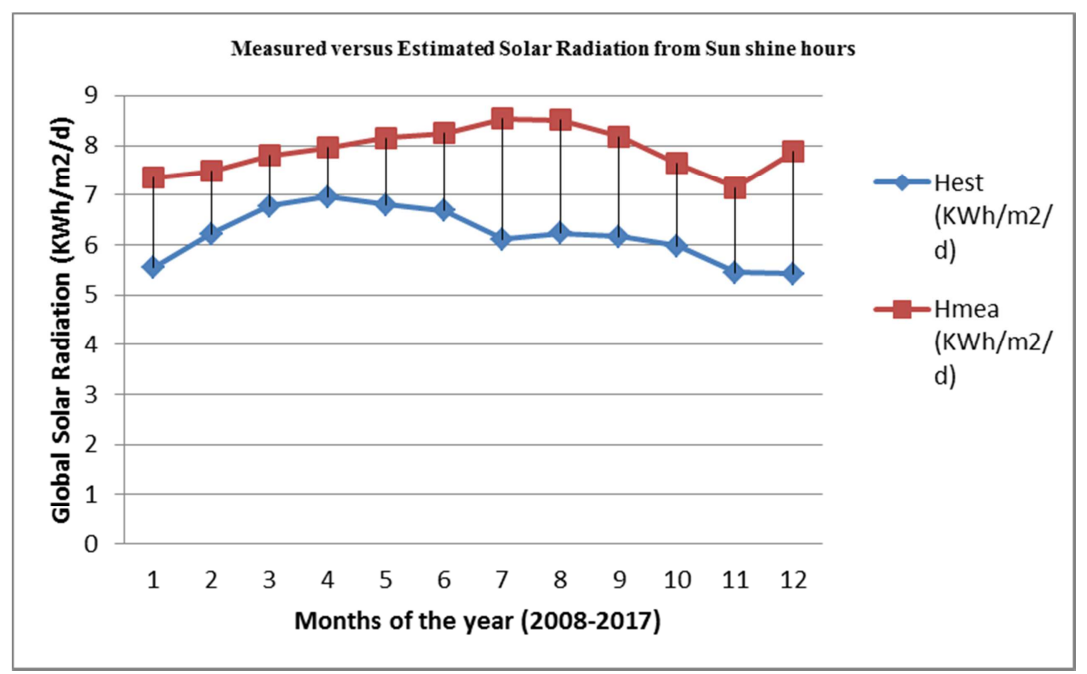

Figure 1. Comparison between Measured Solar Radiation and Estimated solar radiation from sun shine hours. 


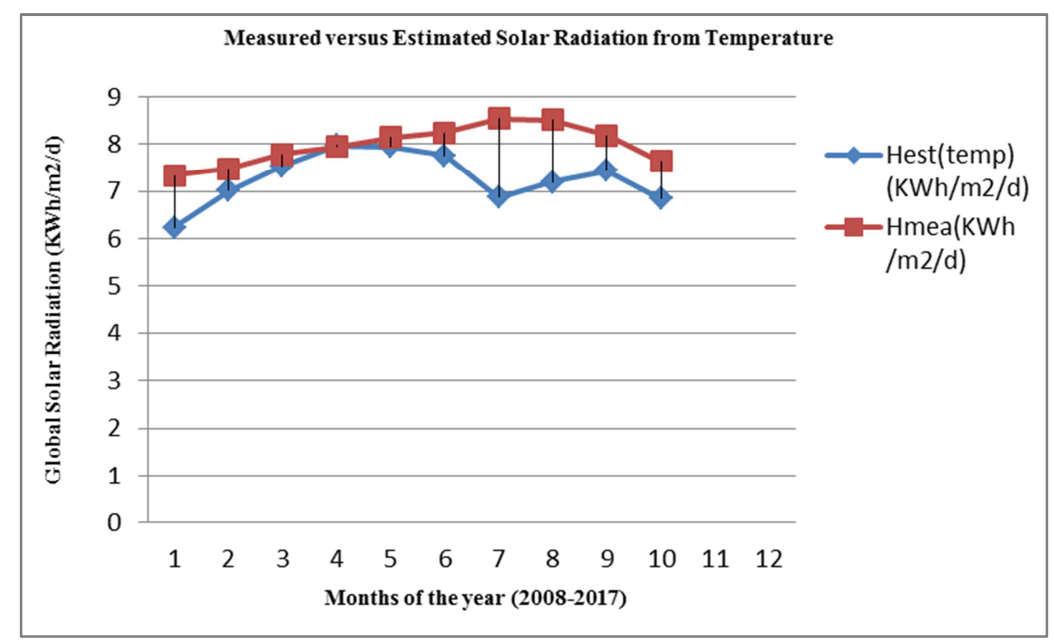

Figure 2. Comparison between Measured Solar Radiation and Estimated solar radiation from temperature.

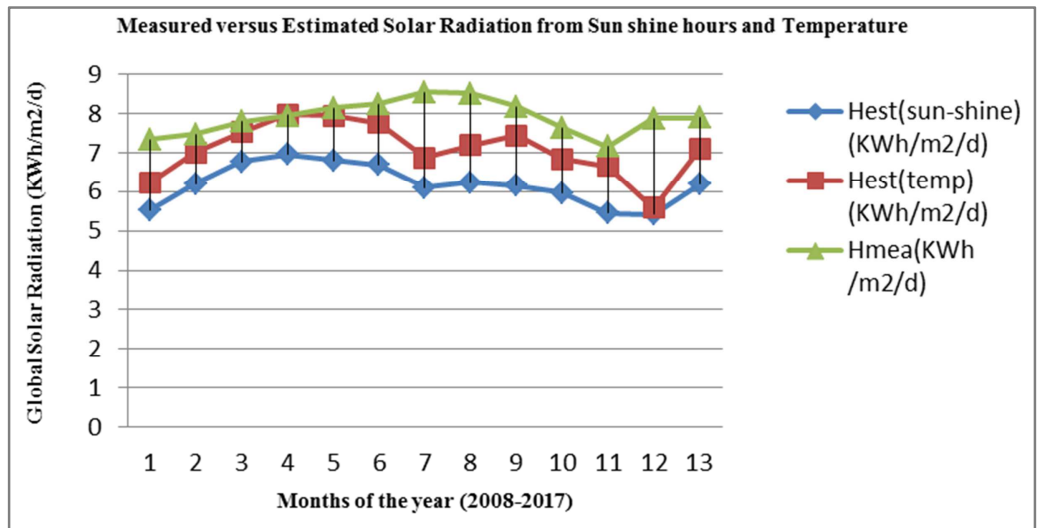

Figure 3. Comparison between Measured Solar Radiation, Estimated solar radiation from temperature and sun shine hours.

The estimated global solar radiation using the two empirical equations and global solar radiation measured from NASA are plotted in Figure 3. It can be observed from the figure that the estimated and the measured global solar radiation using temperature based model are closer to each other than sunshine based model. Hence, the temperature based model has more accuracy than the sun shine based model and this is also indicated by the statistical test in Table 3. The estimated results of sun-shine and temperature empirical based equation were compared with the measured data by using four kinds of statistical error measures: RMSE, MBE, MPE and r. The values of these statistical error indicators are shown in figure 4 and in figure 5 for sun-shine and temperature based empirical equations respectively. Finally the comparison between sunshine and temperature based empirical equations validations due to these statistical errors are shown in figure 6.

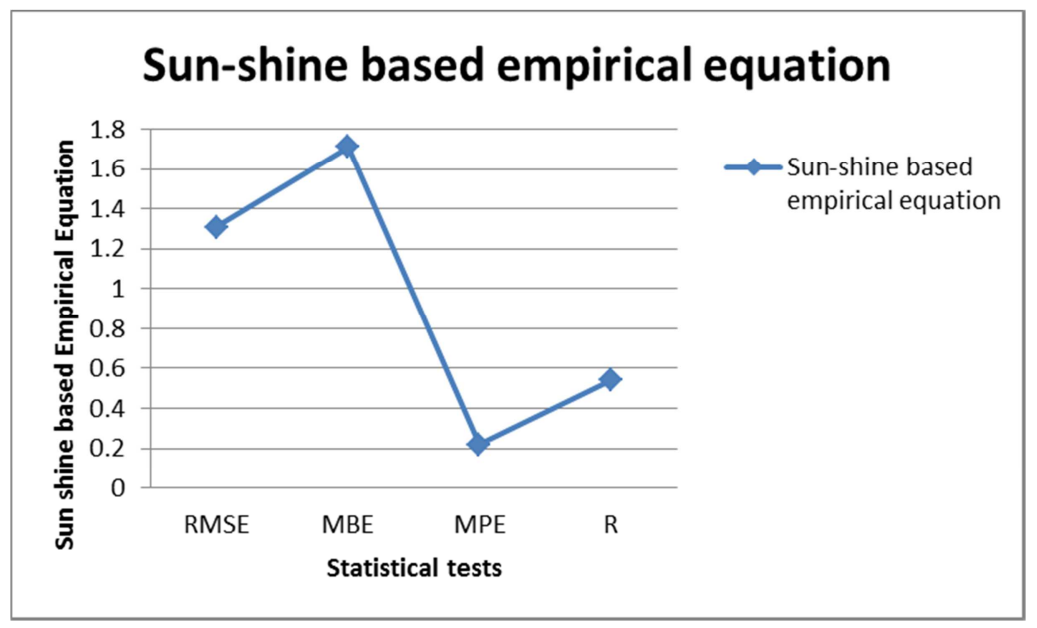

Figure 4. Validation of Sun-shine based empirical equation with different statistical tests. 
The mean percentage error MPE as a test of Goodness of fit is indicated in figure 4, since MPE has a least value for a good fit while a MBE has highest value, which has highest deviation shows in a figure 4 . As showed in figure 4 , the value obtained for the sun shine based empirical equation varies between 0.22 and 1.71 .

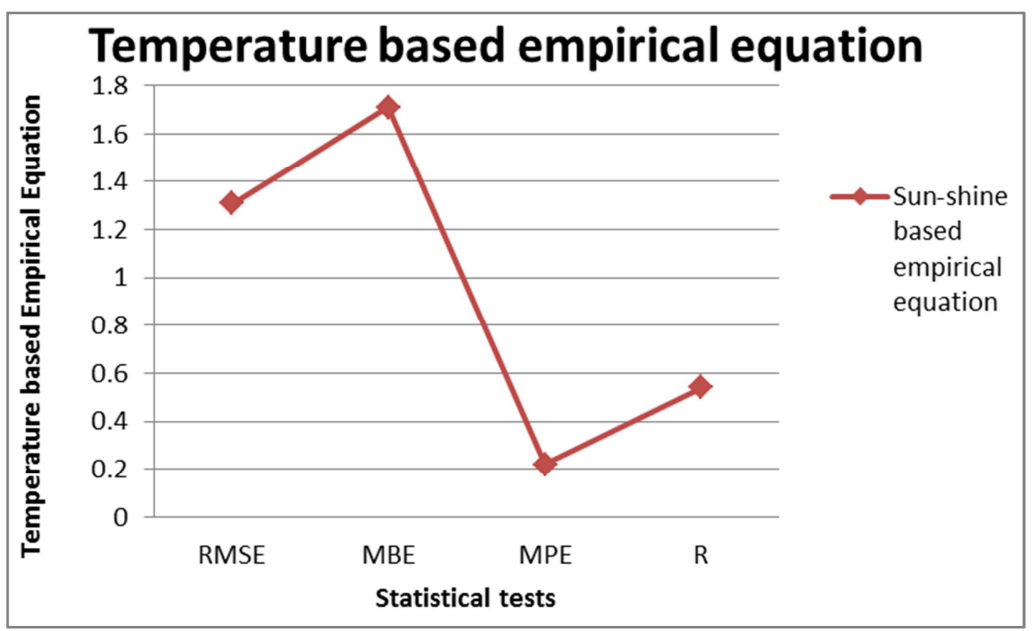

Figure 5.Validation of temperature based empirical equation with different statistical tests.

As showed in figure 5 the statistical tests value obtained for the temperature based empirical equation varies between 0.07 and 0.9 . Correlation coefficient (r) has least value and RMSE has largest value compared with remain statistical tests as shown in figure 5. In statistical test validation always the least value is accepted. Therefore, correlation coefficient (r) as test of Goodness of fit as indicated in figure 5.

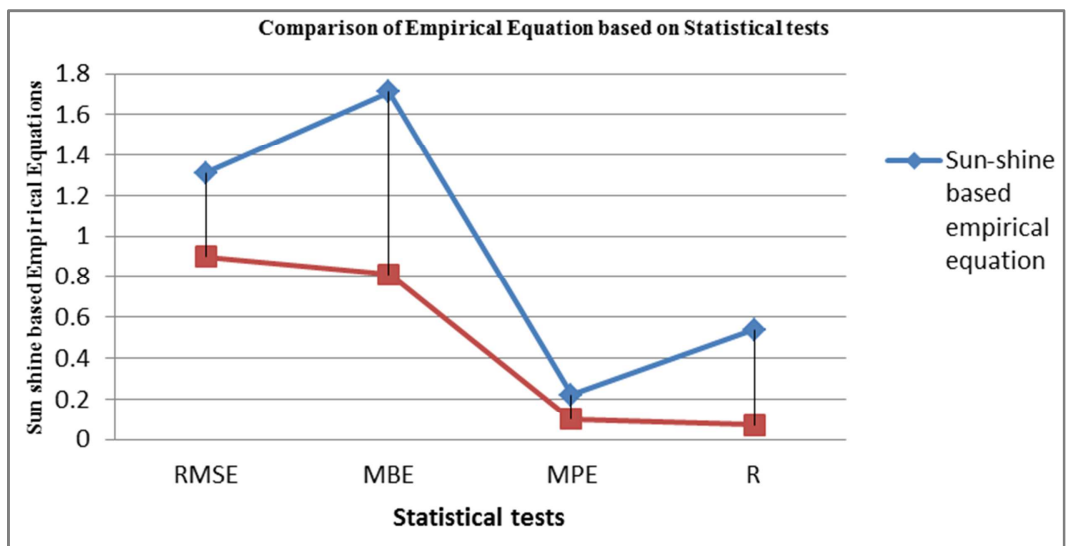

Figure 6. Comparison of temperature and sun-shine based empirical equation with different statistical tests.

For a good empirical equation the difference between estimated and measured global solar radiation should be approach zero. As indicated in figure 6, temperature based empirical equation more accurate in all statistical tests. From table 3 and figure 6 , it is evident that the estimated global solar radiation according Hargreaves and Samani is better than Angstrom-prescott model. Therefore, according to these statistical tests, temperature based empirical equation can be recommended for Kombolcha sites, Amhara region, Ethiopia.

\section{Conclusions}

Assessing global solar radiation is an important requirement for feasibility analysis, design and implementation of solar energy systems. However, unavailability of the measuring instrument in many locations in Ethiopia, particularly
Kombolcha sites, atmospheric parameters (sunshine hours and temperatures) are being used to predict the global solar radiation. In this study, the performance of empirical equation in the prediction of monthly daily mean global solar radiation from sunshine hours (minimum $=5.42 \mathrm{KWh} / \mathrm{m}^{2} /$ day and

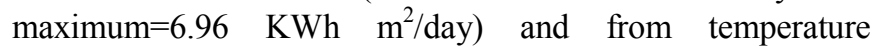
(minimum $=5.59 \mathrm{KWh} / \mathrm{m}^{2} /$ day and maximum $=7.98$ $\mathrm{KWh} / \mathrm{m}^{2} /$ day) have been studied for kombolcha sites. According to the statistical comparison it can be concluded that temperature based empirical equation has more accuracy than the sun shine based. Therefore, the temperature based equation is recommended in any location in Ethiopia with a similar climate. According to [5], the daily average total solar radiation over Ethiopia ranges from 5 to $8 \mathrm{KWh} / \mathrm{m}^{2} /$ day. Therefore, it can be concluded that Kombolcha sites have high potential of mean global solar radiation that estimated from 
sun shine $\left(6.19 \mathrm{Kwh} / \mathrm{m}^{2} /\right.$ day $)$ and from temperature $(7.09$ $\mathrm{KWh} / \mathrm{m}^{2} /$ day) can be used for photovoltaic (PV) and thermal solar energy.Kombolcha is one of the cities of industrial center among the city located in Ethiopia. Therefore, solar power (electricity) will be one of the promising powers used for community as well as industries due to high potential of the site. In addition to these, the study will encourage other research to study more about solar energy throughout the country and will play role in reducing the intermittence of the power in the future, which is the main problem in Ethiopian currently, in particularly Kombolcha.

\section{Acknowledgements}

The authors would like to thank the Kombolcha Meteorological Agency for allowing the use of meteorological data such as sun shine hours, minimum temperature, maximum temperature and average temperature free of charge.

\section{References}

[1] Bahiru B, Mengistu AB. The Challenges of Women Leaders of Business Organizations in Addis Ababa, Ethiopia, in Balancing Work-Family Responsibilities, 2018.

[2] Agbo GA, Alfa B, Ibeh GF, Adamu IS. Application of regression and multiple correlation analysis to morning hours solar radiation in Lapai. International Journal of Physical Sciences. 2013 Jul 23; 8 (27): 1437-41, DOI: 10.5897/IJPS12.323.

[3] Teyabeen AA, Jwaid AE. Sunshine Duration-Based Models for Predicting Global Solar Radiation. In2017 UKSim-AMSS 19th International Conference on Computer Modelling \& Simulation (UKSim) 2017 Apr 5 (pp. 168-172). IEEE, DOI: 10.1109/UKSim. 2017. 32.

[4] Duffie JA, Beckman WA. Solar engineering of thermal processes. John Wiley \& Sons; 2013 Apr 15.

[5] Page CM, Nicholls N, Plummer N, Trewin B, Manton M, Alexander L, Chambers LE, Choi Y, Collins DA, Gosai A, Della-Marta P. Data rescue in the southeast Asia and south Pacific region: challenges and opportunities. Bulletin of the American Meteorological Society. 2004 Oct; 85 (10): 1483-90.

[6] Bekele G, Tadesse G. Feasibility study of small Hydro/PV/Wind hybrid system for off-grid rural electrification in Ethiopia. Applied Energy. 2012 Sep 1; 97: 5-15, https://doi.org/10.1016/j.apenergy.2011.11.059.

[7] Adeniji NO, Akinpelu JA, Adeola SO, Adeniji JO. Estimation of global solar radiation, sunshine hour distribution and clearness index in Enugu, Nigeria. Journal of Applied Sciences and Environmental Management. 2019; 23 (2): 345-9. http://dx.doi.org/10.4314/jasem.v23i2.22.

[8] Podder S, Islam MM. Solar radiation estimation from the measurement of sunshine hours over southern coastal region, bangladesh. International Journal of Sustainable and Green Energy. 2015; 4 (2): 47-53., doi:10.11648/j.ijrse.20150402.14.

[9] Fan, J., Wu, L., Zhang, F., Cai, H., Zeng, W., Wang, X., \& Zou,
H. (2019). Empirical and machine learning models for predicting daily global solar radiation from sunshine duration: A review and case study in China. Renewable and Sustainable Energy Reviews, $100,186-212$, https://doi.org/10.1016/j.rser.2018.10.018.

[10] Fan J, Wu L, Zhang F, Cai H, Zeng W, Wang X, Zou H. Empirical and machine learning models for predicting daily global solar radiation from sunshine duration: A review and case study in China. Renewable and Sustainable Energy Reviews. $2019 \quad$ Feb 1; 100: 186-212, https://doi.org/10.1016/j.bjbas.2017.05.001.

[11] Soulouknga MH, Coulibaly O, Doka SY, Kofane TC. Evaluation of global solar radiation from meteorological data in the Sahelian zone of Chad. Renewables: Wind, Water, and Solar. 2017 Dec; 4 (1): 4.

[12] Medugu DW, Adisa AB, Burari FW, Abdul'Azeez MA. Solar radiation: Correlation between measured and predicted values in Mubi, Nigeria. International Journal of Science and Technology Education Research. 2013 Jan 31; 4 (1): 11-7, DOI: 10.5897/IJSTER11.05.

[13] Ener Ruşen S. Performance evaluation of a coupled method for the estimation of daily global solar radiation on a horizontal surface. Atmósfera. 2018; 31 (4): 347-54, http://dx.doi.org/10.20937/atm.2018.31.04.03.

[14] NASA/POWER,https://power.larc.nasa.gov/downloads /POWER (accessed March 23, 2019).

[15] Chuanyan Z, Zhongren N, Zhaodong F. GIS-assisted spatially distributed modeling of the potential evapotranspiration in semi-arid climate of the Chinese Loess Plateau. Journal of Arid Environments. 2004 Aug 1; $58 \quad(3)$ : 387-403, https://doi.org/10.1016/j.jaridenv.2003.08.008.

[16] Bankar DN, Baviskar VS, Kumar KY, Raskar SS, Khairnar SS, Gite VD, Surve VD, Bagwan JH, Honrao BK. Evaluation of Wheat (Triticum aestivum L.) Genotypes for Changing Climatic Condition under Different Sowing Windows in Semi-Arid Tropics of Western Maharashtra, India. Int. J. Curr. Microbiol. App. Sci. 2018; 7 (4): 761-70, https://doi.org/10.20546/ijcmas.2018.704.085.

[17] Allen RG. Self-calibrating method for estimating solar radiation from air temperature. Journal of Hydrologic engineering. 1997 Apr; 2 (2): 56-67, https://doi.org/10.1061/(ASCE)1084-0699(1997)2:2(56).

[18] Piri J, Kisi O. Modelling solar radiation reached to the Earth using ANFIS, NN-ARX, and empirical models (Case studies: Zahedan and Bojnurd stations). Journal of Atmospheric and Solar-Terrestrial Physics. 2015 Feb 1; 123: 39-47, https://doi.org/10.1016/j.jastp.2014.12.006.

[19] Prescott JA. Evaporation from a water surface in relation to solar radiation. Trans. Roy. Soc. S. Aust. 1940; 46: 114-8.

[20] Korachagaon I, Bapat VN, Magami IA. Few site-independent models for estimating global solar radiation for west and south Asian countries. International Journal of Mechanical and Materials Engineering. 2008; 3 (2): 139-44.

[21] Oyedepo SO. Estimation of global and diffuse solar radiations for se-lected cities in Nigeria. International Journal of Energy and Environmental Engineering. 2011; 2 (3): 13-33. 
[22] Flocas AA. Estimation and prediction of global solar radiation over Greece. Solar Energy. 1980 Jan 1; 24 (1): 63-70, https://doi.org/10.1016/0038-092X(80)90021-3.

[23] Hassan GE, Youssef ME, Mohamed ZE, Ali MA, Hanafy AA. New temperature-based models for predicting global solar radiation. Applied energy. 2016 Oct 1; 179: 437-50, https://doi.org/10.1016/j.apenergy.2016.07.006.

[24] Khorasanizadeh H, Mohammadi K, Jalilvand M. A statistical comparative study to demonstrate the merit of day of the year-based models for estimation of horizontal global solar radiation. Energy conversion and management. 2014 Nov 1; 87: 37-47, https://doi.org/10.1016/j.enconman.2014.06.086.

[25] Li H, Ma W, Lian Y, Wang X, Zhao L. Global solar radiation estimation with sunshine duration in Tibet, China. Renewable $\begin{array}{lllll}\text { energy. } 2011 \quad \text { Nov } 1 ; & 36 & \text { (11): } 3141-5\end{array}$ https://doi.org/10.1016/j.renene.2011.03.019.

[26] Khorasanizadeh H, Mohammadi K. Diffuse solar radiation on a horizontal surface: Reviewing and categorizing the empirical models. Renewable and Sustainable Energy Reviews. 2016 Jan 1; 53: 338-62, https://doi.org/10.1016/j.rser.2015.08.037.

[27] Maluta EN, Mulaudzi ST. Evaluation of the Temperature based Models for the Estimation of Global Solar Radiation in Pretoria, Gauteng province of South Africa. International Energy Journal. 2018 May 31; 18 (2).

[28] Jamil B, Siddiqui AT. Generalized models for estimation of diffuse solar radiation based on clearness index and sunshine duration in India: Applicability under different climatic zones. Journal of Atmospheric and Solar-Terrestrial Physics. 2017 May 1;157:16-34, https://doi.org/10.1016/j.jastp.2017.03.013.

[29] Jamil B, Akhtar N. Estimation of diffuse solar radiation in humid-subtropical climatic region of India: Comparison of diffuse fraction and diffusion coefficient models. Energy. 2017 Jul 15; 131: 149-64, https://doi.org/10.1016/j.energy.2017.05.018.

[30] Pandey CK, Katiyar AK. Solar radiation: Models and measurement techniques. Journal of Energy. 2013 May 12; 2013. http://dx.doi.org/10.1155/2013/30520.

[31] Dos Santos CM, De Souza JL, Junior RA, Tiba C, de Melo
RO, Lyra GB, Teodoro I, Lyra GB, Lemes MA. On modeling global solar irradiation using air temperature for Alagoas State, Northeastern Brazil. Energy. 2014 Jul 15; 71: 388-98, https://doi.org/10.1016/j.energy.2014.04.116.

[32] Liu X, Mei X, Li Y, Wang Q, Jensen JR, Zhang Y, Porter JR. Evaluation of temperature-based global solar radiation models in China. Agricultural and Forest Meteorology. 2009 Sep 1; 149 (9): 1433-46, https://doi.org/10.1016/j.agrformet.2009.03.012.

[33] Adeala AA, Zhongjie HU, Enweremadu Cc. Evaluation of Global Solar Radiation Using Multiple Weather Parameters as Predictors For South Africa Provinces, Thermal Science. 2015 Dec 2; 19, DOI: 10.2298/TSCI130714072A.

[34] Panthee K, Jha AK. Estimation of global solar radiation using Artificial Neural Network in Kathmandu, Nepal. International Journal of Engineering Research and Science. 2016; 2 (1): $62-8$.

[35] Yaniktepe B, Genc YA. Establishing new model for predicting the global solar radiation on horizontal surface. International Journal of Hydrogen Energy. 2015 Nov 26; 40 (44): 15278-83, https://doi.org/10.1016/j.ijhydene.2015.02.064.

[36] Habib I. Estimation of Global Solar Radiation Using Sunshine-Based and Temperature-Based Models; case study of Adama Town (Doctoral dissertation, Haramaya University).

[37] Ozturk M. An evaluation of global solar radiation empirical formulations in Isparta, Turkey. Energy Sources, Part A: Recovery, Utilization, and Environmental Effects. 2015 Nov 17; $37 \quad$ (22): 2474-86, https://doi.org/10.1080/15567036.2012.745037.

[38] Argungu GM, Dabai KA. Application of linear models for estimation of global solar radiation using available meteorological parameters for Sokoto, Nigeria. International Journal of Advances in Scientific Research and Engineering. 2017 Dec; $3 . \quad$ DOI: http://dx.doi.org/10.7324/IJASRE.2017.32556.

[39] Walpole RE, Myers RH, Myers SL, Ye K. Probability and statistics for engineers and scientists. New York: Macmillan; 1993 Jan. 